\title{
THE QUESTION OF PREHISTORIC AGRICULTURE AMONG THE WESTERN YUMANS
}

\author{
By \\ Don Laylander*
}

\begin{abstract}
Agriculture formed an important part of the subsistence system of the prehistoric Yuman-speaking peoples who lived along or near the lower Colorado River. Some recent scholars have argued that the Yumans of northwestern Baja California and southwestern California also practiced agriculture prehistorically. A critical review of the evidence fails to find anysubstantial support for that conclusion.
\end{abstract}

\section{RESUMEN}

La agricultura formaba parte importante del sistema de subsistencia de los pueblos de habla yumana que vivían a lo largo o cerca de la parte baja del río Colorado. Algunos especialistas argumentan que los yumanos de la parte noroeste de Baja California y la parte sudoeste de California también practicaban la agricultura. Sin embargo, al realizar en este artículo una cuidadosa revisión de las evidencias no se encuentra un sustento sólido para esta afirmación.

\section{THE FRONTIER OF PREHISTORIC AGRICULTURE}

At the time of European contact, one of the most conspicuous features in the cultural geography of North America was the line separating agricultural peoples, generally to the south and east, from hunter-gatherers to the north and west. In their archetypal extremes, the agriculturalists included the elaborate, urbanized, hierarchical, state-based civilizations of Mesoamerica, while many hunter-gatherer societies were very small, mobile, technologically simple, and egalitarian.

The division between the two groups was not always sharp. Most North American agricultural peoples also hunted animals and exploited natural plants, for medicines if not as dietary staples. Among some of the

\footnotetext{
* Archaeologist of the Department of Transportation of the State of California, Bishop,
} California. 
agriculturalists, domesticated crops accounted for only a minority of their caloric input. The two subsistence regimes sometimes alternated with each other seasonally within an agricultural community.

On the other side of the frontier, basically non-agricultural peoples were not necessarily purely so. Some hunter-gatherers traded for subsistence products with their agricultural neighbors, or periodically resided among them. Relatively sedentary hunter-gatherers might maintain small gardens, for instance, to grow herbs or tobacco. Without fully domesticating or intensively cultivating crops, some hunter-gatherers actively manipulated the natural environment to improve its yields, for instance by damming small streams and diverting their waters into irrigation ditches to promote riparian plant grown, as among the Owens Valley Paiute of eastern Califomia (Lawton et al., 1976), or by starting fires to weed out old growth and enhance the more favorable early stages in the succession of biotic communities (Lewis, 1973).

The frontier between agriculture and hunting-gathering was neither geographically simple nor stable through time. Pockets of hunter-gatherers lived in the midst of generally agricultural regions, and oases of agriculture were planted well ahead of the main frontier. In so far as the division was based on natural conditions - in particular, the availability of water at appropriate times of year, and the length of the growing season-changes in the frontier might be expected to have been minor, or to have taken place only very slowly. However, there were also clearly involved other factors of a cultural character, such as the gradual outward diffusion of agricultural technology, the stimulus to subsistence intensification, due to burgeoning populations, and competitive pressures to hold territories against expansionist neighbors. Agriculture can be traced back in the archaeological record of Mesoamerica at least 9,000 years, but it was expanding its domain in North America considerably during the last 2,000 years before European contact. There were also retreats as well as advances, for instance in the withdrawal of agriculture from parts of the Great Basin and the southwestern United States around 700 years ago.

The permeability of the agricultural frontier is perhaps most dramatically illustrated by the manner in which it freely cut across linguistic boundaries. For instance, the widespread Utoaztecan family included the continent's most elaborate state-level societies in central Mexico: the agricultural villages of the Pimans in Sonora and southern Arizona, and the Hopi towns of northern Arizona; also, the relatively complex Takic-speaking hunter-gatherers of coastal southern California and the highly mobile and socially-fragmented Numic-speaking foragers of the Great Basin. 
Despite its gradational, irregular, and unstable character, the agricultural frontier represented an important threshold in cultural evolution. On the one side were lifeways which were organized primarily around the satisfaction of immediate personal or familial needs. On the other side was a system in which labor was invested toward delayed future returns. Because the realization of those future returns was tied to the control of particular locations, the yields were vulnerable to being diverted to other ends, whether in the name of force, custom, or law. Investment and the diversion of its fruits provided the essential foundation for an elaboration of sophisticated arts and sciences. They also set societies on the slope leading rapidly down from essential egalitarianism to the subordination of most members' interests to those of a privileged elite.

\section{YUMAN-COCHIMÍ ADAPTATIONS: THE COCHIMÍ AND THE UPLAND YUMANS}

Like the Utoaztecans, although on a smaller geographical scale, the Yuman-Cochimf linguistic group (Figures 1 and 2) embraced considerable diversity in subsistence regimes and other aspects of culture. This diversity emerged from additions to, and divergences within, a common cultural tradition which dated back to a single language community perhaps 6,000 years ago (Laylander, 1993).

At one end of the scale of social and cultural complexity were the Cochimi of the central Baja California desert. The Cochimi lived in small, independent, highly mobile, and relatively egalitarian communities. Their subsistence was derived from a wide range of native plants, some coastal resources, and such game as was available (cf. Aschmann, 1959; Laylander, 1987).

The Upland Yumans of western Arizona have conventionally been distinguished as the Yavapai, Walapai, and Havasupai. The lifeways of these peoples have been compared in many respects to those of their northern neighbors, the Numic-speaking Utoaztecans of the Great Basin. Occupying the land sparsely and moving often, the Upland Yumans were socially and politically fragmented. Their subsistence has generally been considered to have derived primarily from hunting and gathering. However, some agriculture was practiced; its overall importance has been debated, but that issue will not be pursued here (cf. Dobyns and Euler, 1976; Kroeber, 1935). 


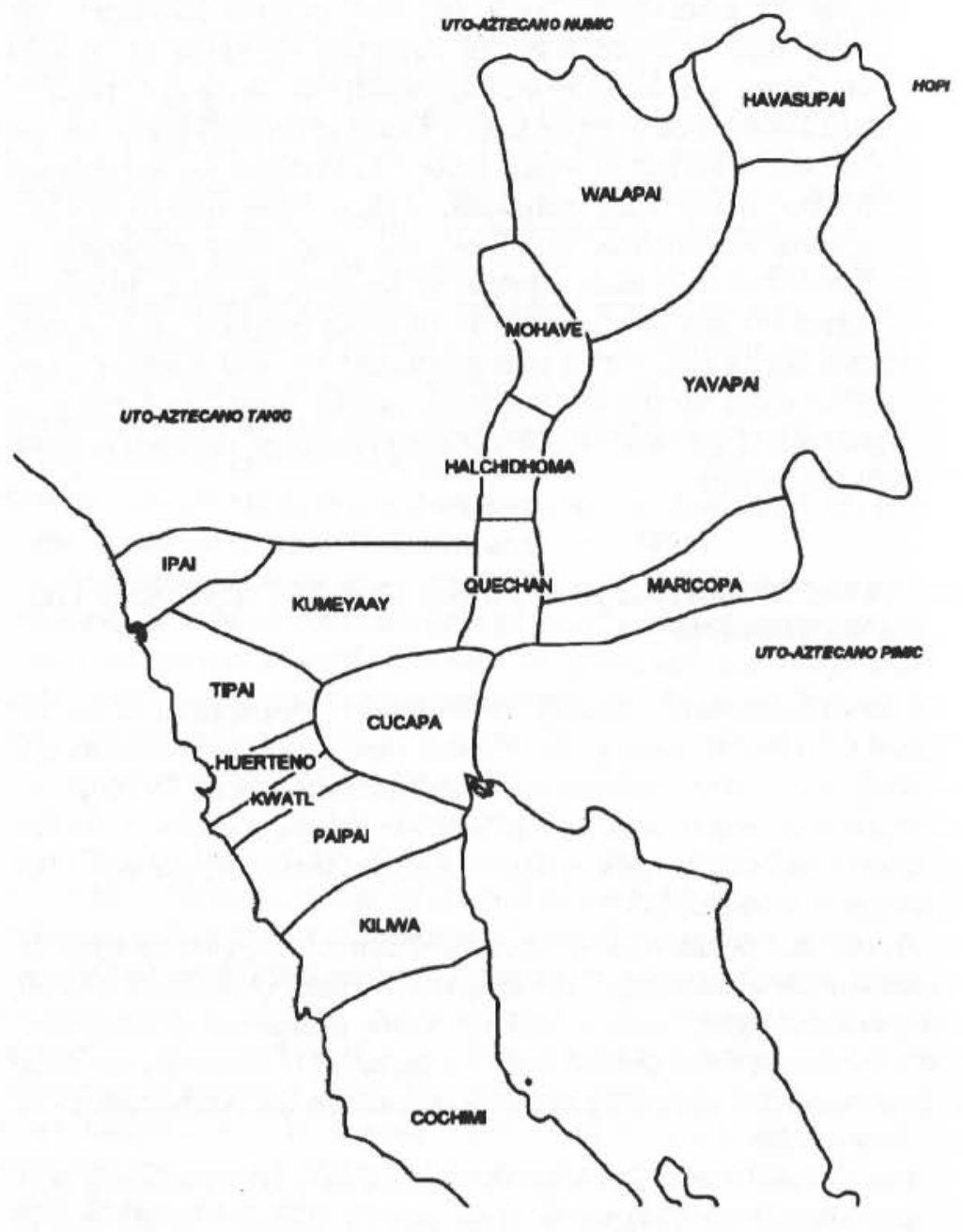

Figure 1. Native Languages of Eastern Arizona, Southern California and Northern Baja California. 


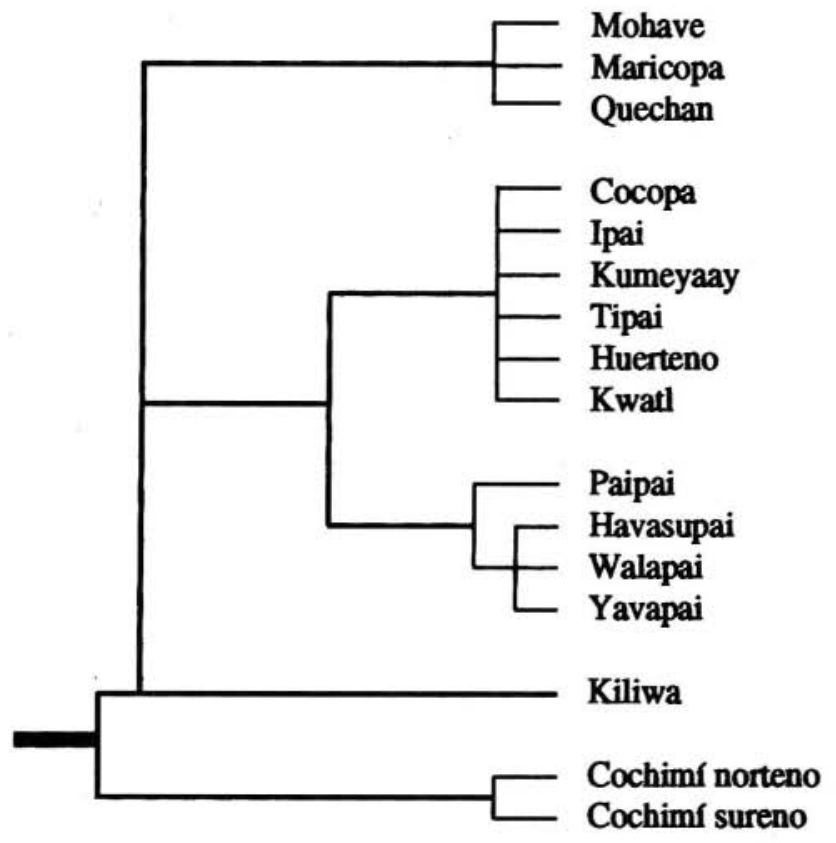

Figure 2. Genetic Classification of the Yuman-Cochimi linguistic group.

\section{YUMAN-COCHIMÍ ADAPTATIONS: THE RIVER YUMANS}

The River Yumans lived on the banks of the lower Colorado and Gila rivers and in the Colorado River delta, in southeastern California, western Arizona, and northern Baja California. Included were the Mohave, Quechan, Maricopa, and Cucapa, as well as other groups which are more shadowy in the ethnographic record, such as the Halchidhoma, Kavelchadom, Halyikwamai, and Kahwan. The eastern Kumeyaay of Mexicali- Imperial Valley, although closely linked with their Western Yuman kin, seem to have shared the essentials of their lifeways with the River Yumans (Gifford, 1931). 
The River Yumans had relatively dense populations, an unusual tendency toward a tribal level of political integration above the local communities, and a virulent pattern of inter-ethnic alliances and chronic large-scale warfare. They were also agriculturalists.

The presence of crop-growing among the River Yumans was reported by all the historic-period observers, from Hernando de Alarcon in 1540, onward. Thorough accounts of River Yuman agriculture have been written by F.B.Kniffen (1931), Edward W. Gifford (1931, 1933), Philip Drucker (1941), Edward F. Castetter and Willis H. Bell (1951), and William H. Kelly (1977). Corn (Zea mays), tepary beans (Phaseolus acutifolius), pumpkins (Cucurbita moschata), and bottle gourds (Lagenaria siceraria) were cultivated by the Cucapa, and "incipient cultivation" of cotton (Gossypium hopi) and "semicultivation" of several wild seed plants (Castetter and Bell, 1951:167-178) were practiced. It has been estimated that in the middle of the nineteenth century agriculture accounted for about $30 \%$ of the food supply of the Cucapa (Castetter and Bell, 1951:74). Kumeyaay agriculture in the Mexicali-Imperial Valley seems to have been substantially the same.

River Yuman crops had evidently diffused to the region prehistorically from the east or south, probably from the Pimans. Several Old World crops, including black-eyed beans, watermelons, muskmelons, wheat, and barley, also reached the River Yumans ahead of the frontier of Euramerican control, and were incorporated into the "aboriginal" subsistence system. It is not clear whether the introduced crops, displaced additional prehistoric crops, and whether they altered the pattern and importance of agriculture within the subsistence system.

Aboriginal agriculture in the Colorado River delta was based almost entirely on the river's natural seasonal flooding. The Colorado River overflowed its banks in a summer crest which was irregular in timing and size. Planting was done in the moist soil as the flood receded. Water control systems, including dams, levees, and ditches, were apparently used (Kelly, 1977:27-28), but only on a very limited scale. Other items of agricultural technology, such as simple and chisel-end planting sticks, side-scraper hoes, scarecrows, and platform granaries, represented only modest elaborations of the technology which was otherwise used for wild plant resources.

\section{YUMAN-COCHIMÍ ADAPTATIONS: THE WESTERN YUMANS}

To the west, in the mountains, inland valleys, and coastal plains of northwestern Baja California and southwestern California, lived other 
Yuman-speaking groups: Kiliwa, Paipai, and Diegueño (including Kwatl, Huerteño, Tipai, Kumeyaay, and Ipai language communities; cf. Laylander, 1993). The lifeways of these groups, as portrayed in most accounts, can be characterized as intermediate in cultural complexity between those of the Cochimi and the River Yumans. Population densities, community sizes, degree of sedentism, degree of sociopolitical integration above the family level, and technological elaboration were all probably greater among the Western Yumans than among the Cochimi, but less than among the River Yumans.

Ethnohistoric descriptions and early ethnographies agreed that the subsistence of the Western Yumans was based on the hunting and gathering of a wide range of naturally-occurring plant and animal resources, although the western peoples were obviously aware of River Yuman agriculture (cf. Drucker, 1937:11, 1941:94; Hicks, 1963:286; Kroeber, 1925:722; Meigs, 1939:22). Most prehistorians continue to regard the prehistoric Western Yumans as non-agricultural peoples.

However, some scholars have dissented from this conclusion. Since the 1960's, a revisionist school of ethnographers has argued that the Western Yumans and other aboriginal southern Califomia peoples had more "advanced" cultures than previously thought, with respect to such matters as the complexity of their sociopolitical organization, degree of social inequality, population density, elaboration of idea-systems, and subsistence technology (cf. Laylander, 1991). In this context, the specific issue of prehistoric agriculture merits a critical review.

\section{ETHNOHISTORIC EVIDENCE FOR WESTERN YUMAN AGRICULTURE}

Possible ethnohistoric evidence for Western Yuman agriculture was discussed by Jack D. Forbes (1963) and by Lowell John Bean and Harry W. Lawton (1973). Forbes adduced arguments for the existence of aboriginal agriculture in several regions west and northwest of the Colorado River, including the Western Yuman region. In part, his arguments related to agricultural practices which were "aboriginal" in the sense of being done on the initiative of the Indians themselves, rather than under Euramerican direction, but not necessarily in prehistoric or precontact times, and not necessarily independent of strong Euramerican influences. Such a distinction is fair enough, but is not to be confused with the one of primary concern here, which is the distinction between prehistoric and historic agriculture, or between pre- and post-contact cultural patterns. Bean and Lawton somewhat blurred this distinction in 
reviewing Forbes' evidence. They concluded that "the case for aboriginal agriculture in northern Baja California appears established" (Bean and Lawton, 1973:xv; see also Lawton, 1974:63).

One piece of evidence cited by Forbes is an early ethnographic report by Edward W. Gifford:

At Jacumba, in the mountains of Eastern Diegueño territory, the several lineages planted watermelons, pumpkins, maize, teparies, and cowpeas. The conditions of cultivation were different from those in Imperial Valley, there being no inundation by river waters, but the conducting of water in ditches from a spring... The flow was regulated by a dam. This was on the Mexican side of the international boundary. Jose, the informant [said to be between 90 and 100 years old in the late 1920 's], insisted that no Mexicans were there at the times he visited; but it seems that this type of planting must have been due to Caucasian influence, perhaps from the Missions. In addition to five Kamia [i.e., eastern Kumeyaay] lineages from Imperial Valley...planting at Jacumba, there was one Eastern Diegueño lineage....which also planted, although never going to Imperial Valley to do so (Gifford, 1931:22).

Forbes argued that this testimony was evidence of pre- contact agricultural practices, claiming that "the Indians of Jacumba were never missionized except perhaps for a few individuals" (Forbes, 1963:6). However, it is not at all certain that strong influences from the missions, or from former mission Indians, were absent from the Jacumba area at the period in question. That period must have been at least as late as the 1830 's, subsequent to the disruptions of mission secularization.

A second argument offered by Forbes relates to a report by the Spanish explorer Alarcon, who visited the Colorado River Delta in 1540. Forbes observed:

In 1540 Hemando de Alarcón was told by Naguachato, the chief of a group of delta Indians, that the mountain people to the west lived in a 'desert place that produced little maize, [therefore] they came down to the plains to get it in trade'. This would indicate that the mountaineers (probably Kamias [i.e., Dieguefío speakers] or Paipais) were both maizeusing and to some extent maize-growing in 1540 (Forbes, 1963:9).

The passage from Alarcon which was cited by Forbes, in fact referred to people from "a mountain" but did not specify whether the mountain lay to the east or the west. The mountaineers were said to be very warlike, to make long skirts of sewn buckskin, and to live in big stone houses (Hammond and Rey, 1940:II, 138), none of which traits sound 
characteristic of the Western Yumans, as they are otherwise known ethno historically and ethnographically. Whatever region or ethnic group may be meant by the reference, an indirect report that their homeland "produced little maize" can carry little weight as proof that the homeland did in fact produce any maize at all. A cautious interpretation is suggested by remembering the fantastically inaccurate accounts of peoples who were not actually visited, which sixteenth- and seventeenth-century Spanish explorers often reported receiving from the peoples whom the Spanish did meet (e.g., Hammond and Rey, 1953:1012-1031).

As a third piece of evidence, Forbes quoted a May, 1788, report from the Dominican mission of San Vicente:

...noticia un Indio cristiano de esta misión que en la tierra de esta parte han sembrado los indios gentiles, maíz, frijol, calabazas, melones y sandías, y que estas semillas las han traído del Colorado, y que éstos van cada instante allá, y los del Colorado vienen a dicha ranchería donde está la siembra (Forbes, 1963:9). ${ }^{1}$

This seems a good example of "aboriginal" agriculture in Forbes' limited sense of agriculture on aboriginal initiative, but not necessarily following a pattern of prehistoric agriculture. However, Bean and Lawton (1973:xvi) asserted that in this instance "mission diffusion is unlikely, since crop-growing was not yet established at this mission".

Several objections can be raised to the argument that the 1788 report from San Vicente necessarily reflects an agricultural pattern predating European influences. The location of the San Vicente mission was visited several times before the mission was established. The Portola-Serra expeditions of 1769 passed through the valley in the late spring, noting that it "has arable land with plenty of moisture and is even marshy" but giving no suggestion of aboriginal agriculture, which would certainly have been considered noteworthy (Bolton, 1927). In early 1780, the soldier José Velasquez scouted the same area, looking for a site for the mission which would be established there later the same year. The nature of the terrain and its agricultural possibilities were described by Velásquez, both verbally and in a detailed sketch map, but no suggestion was made that there was any ongoing aboriginal agriculture at or near the location (Ives, 1984:144-149).

1 .... Chrigtian Indian of this mission brings the news that in the land of this place the Gentile Indians have planted corn, beans, squash, cantaloupes, and watermelons, and that they have brought these seeds from the Colorado, and that they go always there, and they of the Colorado come to the ranch where the plantings are. (Forbes, 1963:9). 
There appears to be no foundation to the claim of Bean and Lawton that mission diffusion could nothave been involved in the San Vicente agricultural experiments because crop growing had not yet been established at San Vicente in 1788. The mission of San Vicente was founded in 1780 and quickly became, in effect, the capital of the Dominican frontier district (Meigs, 1935:80). It was one of the few Dominican sites chosen successfully enough that the mission did not have to be moved later (Meigs, 1935:24). Bean and Lawton did not make clear the basis for their assertion that crops were not yet grown at San Vicente after eight successful years, but the source may lie in a misprint. In a summary table of mission crops and herds published by the geographer Peveril Meigs (1935:166), the first entry for San Vicente bore the date "1792" (Table 1). That this date was a misprint for "1782" is shown both by the reference which Meigs gave for the statistic, "Arch. Cal., S.P., 1:22", which was cited in the same table for 1782 statistics relating to missions at $\mathrm{El}$ Rosario and Santo Domingo, and also by the San Vicente entries which follow in the same table, having dates of $1784,1785,1786,1787$, and 1788 , with crops of various sizes listed for these years. The Dominican missionary Luis Sales (1960) produced a table reporting substantial yields in corn and wheat at San Vicente for the year 1788. Clearly, mission agriculture was successfully practiced at San Vicente for several years before 1788 .

The example of aboriginal agriculture at San Vicente, referred to in the 1788 quotation, involved seeds which had been brought from the Colorado River, rather than being procured from a local non-mission source. Specific reference was made to significant levels of interaction between the local unconverted Indians (gentiles) and river Indians. These circumstances suggest that agriculture was locally a freshly-introduced trait, rather than one of long standing. The fact that the San Vicente area apparently pertained to the Paipai linguistic group and the reported presence of Paipai settlements on the Colorado River among the Cucapa at least as early as the 1820 's also point to strong historic-period interactions between the peoples of the two areas (cf. Laylander, 1987). The events of the early 1780 's suggest that the relationship between San Vicente and the lower Colorado River was changing during that decade. In 1781, the Franciscan missions in Quechan territory on the lower Colorado River were destroyed by an Indian revolt. For several years thereafter, uncertainties hung over both the San Vicente area and the delta, in the first case because of fears of a coordinated Indian revolt or attack; and in the second case because of projected Spanish punitive expeditions to the river (Sales, 1960; Meigs, 1935:24). In 1782, a major smallpox epidemic hit San Vicente, and $27 \%$ of that mission's population was reportedly buried 
TABLE 1. San Vicente Mission Crops and Herds (after Meigs, 1935:166).

\begin{tabular}{|c|c|c|c|c|c|c|c|c|c|c|}
\hline Year & Cattle & Sheep & Goats & Horses & $\begin{array}{l}\text { Mules } \\
\text { \& Burros }\end{array}$ & $\begin{array}{l}\text { Bu., @ } \\
\text { Wheat }\end{array}$ & $\begin{array}{l}2.6 \text { bu.pe } \\
\text { Barley }\end{array}$ & $\begin{array}{l}\text { fanega } \\
\text { Corn }\end{array}$ & Beans & Source \\
\hline 1792 & 56 & 114 & 27 & 6 & 40 & 520 & 65 & 5 & 5 & Arch.Cal.,S.P.,1:22 \\
\hline 1784 & 178 & 517 & 141 & 63 & 34 & 650 & $\ldots$ & 676 & $\ldots$ & Arch.Cal.,S.P.,1:31-32 \\
\hline 1785 & 153 & 457 & 27 & 59 & 33 & 354 & $\ldots$ & 614 & $\ldots$ & Arch.Cal.,S.P.,1:37 \\
\hline 1786 & 170 & 603 & 31 & 76 & 40 & 783 & $\ldots$ & 1568 & $\ldots$ & Arch.Cal.,S.P.,1:43-44 \\
\hline 1787 & 150 & \multicolumn{2}{|c|}{$--633--$} & 65 & 25 & 468 & $\ldots$ & 598 & $\ldots$ & Arch.Cal.,S.P.,1:51 \\
\hline 1788 & 152 & \multicolumn{2}{|c|}{$--644-$} & 72 & 25 & $\ldots$ & $\ldots$ & $\ldots$ & $\ldots$ & Arch.Cal.,S.P.,1:55-57 \\
\hline 1793 & 178 & 748 & 69 & 155 & 50 & 780 & $\ldots$ & 1040 & 52 & Arch.Cal.,S.P.,1:126-131 \\
\hline 1794 & 242 & 548 & 69 & 157 & 61 & 192 & $\ldots$ & 1560 & $\ldots$ & Arch.Cal.,S.P.,2:9-10 \\
\hline
\end{tabular}


that year. Nonetheless, the mission's period of most rapid recorded growth occurred between 1782 and 1785 . Evidently substantial numbers of gentiles were being drawn to the location from elsewhere (Meigs, 1935:24. 81-82).

Another objection to the 1788 San Vicente testimony as evidence for pre-contact agriculture concerns the identity of the crops being raised: com, beans, pumpkins, muskmelons, and watermelons. These crops do indeed suggest an agricultural pattem more typical of the lower Colorado River than of the Dominican mission system in Baja California (Castetter and Bell, 1951; Kelly, 1977). However, two of the crops, muskmelons and watermelons, were European introductions to the New World, long since established on the lower Colorado River, but clearly not part of a prehistoric cultural pattem.

Bean and Lawton proposed one further piece of evidence for pre-contact agriculture in or near the Western Yuman region:

On April 13, 1785, Second Lt. José Velásquez, four days out of San Diego and probably about 20 to 40 miles south of Jacumba in northem Baja, climbed a hill to survey the desert plain. He noted smoke at the base of the mountains, and was told by his Indian guide that this was a ranchería where wheat was planted (Bean and Lawton, 1973:xvi).

A location 20 to 40 miles south of Jacumba would have put Velasquez opposite the northern or central portion of the Laguna Macuata Basin, roughly opposite Palmas de Cantú or Cañon de Guadalupe. Ethnographic evidence indicates that when flooding conditions permitted, the Cocopa planted fields in some portions of the Laguna Macuata Basin (Kelly, 1977:21). Crops grown in this area would probably have been an extension of the delta complex, rather than evidence of Western Yuman agriculture.

The point is made moot by the geographer Ronald L. Ives' (1984) detailed reconstruction of Velásquez's 1785 route (Figure 3). On April 13, Velásquez was five days' travel from San Vicente, and still seven days from San Diego. According to Ives, the observations of April 13 were made, not 20 to 40 , but a about 80 miles southeast of Jacumba, near Arroyo Grande, overlooking the junction of the Laguna Macuata Basin with the main portion of the Colorado River Delta. Agricultural fields in this area, near the heart of Cucapa territory, would have no bearing on the issue of Western Yuman agriculture.

\section{ETHNOGRAPHIC EVIDENCE}

The ethnographer Florence C. Shipek (1982, 1987, 1993a, 1993b) has been a firm and persistent advocate for the existence of an elaborate pre-contact 


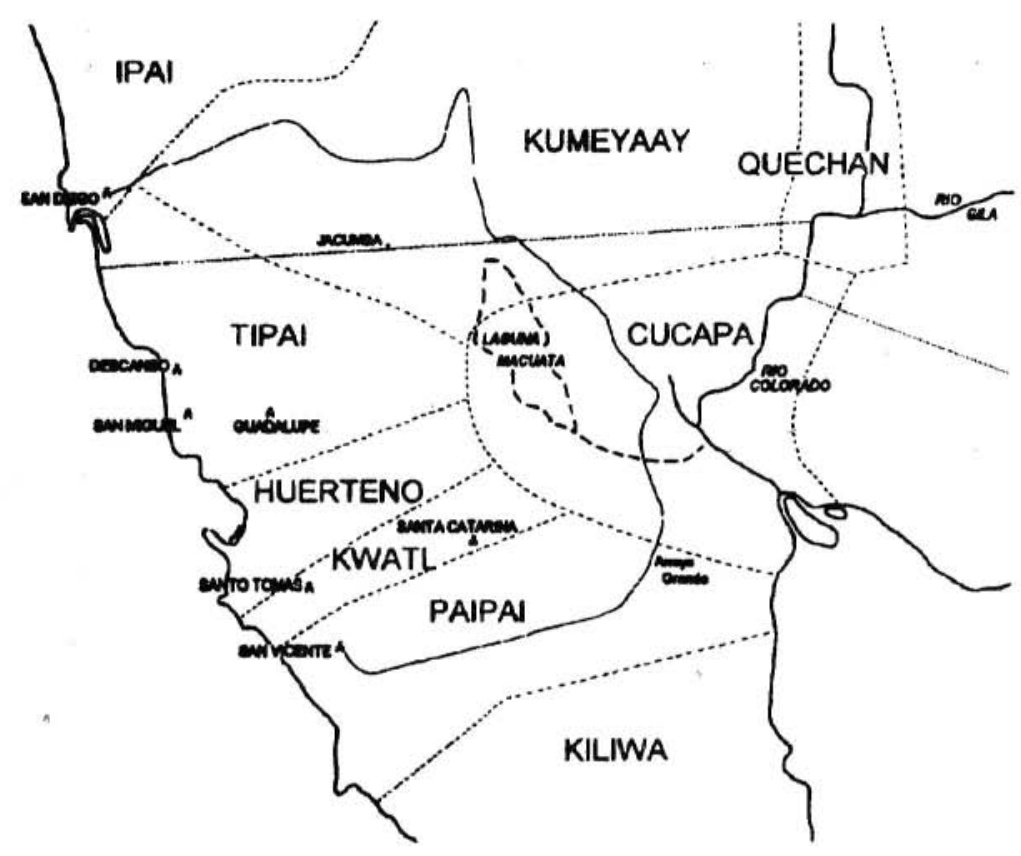

Figure 3. Territories of the Different Yuman Linguistic Groups.

agriculture among the western Diegueño groups. According to Shipek, those groups practiced

intensive plant husbandry of native food resource plants... combined with broadcast of a native semi-domesticated grass seed (now extinct), fire swidden of chaparral for food resources, and planting of corn, beans, and squash in selected mountain and desert locations having appropriate summer moisture (Shipek, 1982:296). 
In Shipek's view, the early Spanish explorers and missionaries simply overlooked the existence of agricultural practices in this region:

...los españoles no apreciaron el tipo de campos desmontados y con cultivos de los indígenas, los invasores consideraron a los kumiai como simples recolectores de lo que la naturaleza producía. No reconocieron el trabajo involucrado en los campos plantados alternativamente en taludes de colinas... Debido a que los arbustos y árboles de temporada se daban en algunas cuantas colinas naturales, los españoles veían a todos los encinos, arbustos de chaparral y especies de temporada como silvestres y no como recursos alimenticios en huertos y campos deliberadamente sembrados y administrados... Los registros españoles indican que no se internaron en las regiones de las montañas y zonas desérticas donde pudieran haber visto cultivos que hubieran reconocido tales como maíz, calabaza y frijol en una temporada en que esos cultivos debieron estar en los campos (Shipek, 1993a:63-64). ${ }^{2}$

As thus far published, Shipek's view in this matter has been based on assertion rather than evidence. Earlier ethnographers had consistently arrived at opposite conclusions, as, has been noted above. It seems improbable that any late twentieth century ethnographic testimony concerning mid-eighteenth century conditions and practices could convincingly overrule the mass of earlier ethnographic and ethnohistoric evidence.

\section{ARCHAEOLOGICAL EVIDENCE}

Archaeological investigations may be able to shed some light on this matter in the future. No compelling archaeological support for the existence of prehistoric Western Yuman agriculture has been found as yet.

The archaeologist Adan E. Treganza (1947) found two caches of maize cobs in the Jacumba area in 1939, and in 1943 he found another cache of several ceramic vessels with seeds of nine domesticated species. The seeds

2

...the Spanish did not take note of, nor appreciate Indians' cleared growing crops. The invaders considered the Kumiai to be simple gatherers of whatever Nature produced. They did not recognize the labor invested in the sown fields or the hillside plantings.. Due to the fact that some of the bush-type annuals and trees grew as natural volunteers on some hillsides, the Spaniards saw all the oaks, chaparral-type bushes and annual species as wild plants and not as food resources deliberately planted and cultivated in orchards and fields... The Spanish registries indicate that they did not go into those mountainous regions and desert zones where they could have seen crops that they would have recognized (corn, squash, and beans) at the time of year when those crops would have been growing in the fields (Shipek, 1993a:63-64). 
included species introduced during the historic period, and the 1943 cache also contained a piece of post-1850's textile. Treganza felt that the types of seeds showed closer similarities to the Colorado River agricultural complex than to the mission agricultural complex, and that the find at least raised the question of a possible long-established aboriginal agriculture. As has been noted, other evidence also points to the role of Colorado River agricultural borrowings in the Western Yuman region during the post-contact period, without necessarily suggesting any pre-contact agricultural practices.

\section{SUMMARY}

The question of possible prehistoric Westem Yuman agriculture is of interest for its bearing on broader issues concerning the mechanisms and conseciuences of changes in the frontier of prehistoric agriculture, and in relation to the role of agriculture as cause and effect in cultural evolution. Future ethnohistoric and archaeological investigations may be able to shed further light on the question. However, the evidence offered to date does not provide grounds for concluding that agriculture played any significant role prehistorically in the Western Yuman region. 


\section{BIBLIOGRAPHY}

ASCHMANN, Homer. 1959. "The Central Desert of Baja California: Demography and Ecology". Iberoamericana 42.

BEAN, Lowell John, y Harry W. Lawton. 1973. "Some Explanations for the Rise of Cultural Complexity in Native California with Comments on Proto-Agriculture and Agriculture". In: Henry T. Lewis, Patterns of Indian Burning in California: Ecology and Ethnohistory. Ballena Press, Ramona, California.

BOLTON, Herbert E. 1927. Fray Juan Crespi, Missionary Explorer on the Pacific Coast, 1769-1774. University of California Press, Berkeley.

CASTETTER, Edward F., y Willis H. Bell. 1951. Yuman Indian Agriculture. University of New Mexico Press, Albuquerque.

DOBYNS, Henry F., y Robert C. Euler. 1976. The Walapai People. Phoenix: Indian Tribal Series.

DRUCKER, Philip. 1937. "Culture Element Distributions: V. Southern California". University of California Anthropological Records $1: 1-52$.

- 1941. "Culture Element Distributions: XVII. Yuman-Piman". University of California Anthropological Records 6:91-230.

FORBES, Jack D. 1963. "Indian Horticulture West and Northwest of the Colorado River". Journal of the West 2:1-14.

GIFFORD, Edward W. 1931. "The Kamia of Imperial Valley". Bulletin of the Bureau of American Ethnology 97.

- 1933. "The Cocopa". University of California Publications in American Archaeology and Ethnology 31:257-334.

HAMMOND, George P., y Agapita Rey (eds.) 1940. Narratives of the Coronado Expedition, 1540-1542. University of New Mexico Press, Albuquerque.

- 1953. Don Juan de Oñate, Colonizer of New Mexico. University of New Mexico Press, Albuquerque.

HICKS, Frederic Noble. 1963. Ecological Aspects of Aboriginal Culture in the Western Yuman Area. Ph.D. dissertation, University of California, Los Angeles.

IVES, Ronald L. 1984. José Velásquez: Saga of a Borderland Soldier (Northwestern New Spain in the 18th Century). Southwestern Mission Research Center, Tucson, Arizona.

KELLY, William H. 1977. Cocopa Ethnography. Anthropological Papers of the University of Arizona, No.29. 
KNIFFEN, F.B. 1931. "The Primitive Cultural Landscape of the Colorado Delta". University of California Publications in Geography 5:149-244. KROEBER, A.L. 1925. Handbook of the Indians of Califormia. Bureau of American Ethnology Bulletin 78.

- 1935. "Walapai Ethnography". Memoirs of the American Anthropological Association 42.

LAWTON, Harry W. 1974. "Agricultural Motifs in Southem California Indian Mythology". Journal of California and Great Basin Anthropology 1:52-79.

LAWTON, Harry W., Philip J. Wilke, Mary DeDecker, y William M. Mason. 1976. "Agriculture among the Paiute of Owens Valley". Journal of California Anthropology 3:13-50.

LAYLANDER, Don. 1987. "Sources and Strategies for the Prehistory of Baja California". Master's thesis. Department of Anthropology, San Diego State University.

- 1991. "Organización comunitaria de los yumanos occidentales: Una revisión etnografica y prospecto arqueologico". Estudios Fronterizos 24/25:31-60.

- 1993. "Enfoques lingüísticos sobre la prehistoria del sur de California". Estudios Fronterizos 31/32:9-60.

LEWIS, Henry T. 1973. Patterns of Indian Burning in California: Ecology and Ethnohistory. Ballena Press, Ramona, California.

MEIGS, Peveral, III. 1935. "The Dominican Mission Frontier of Lower "California". University of California Publications in Geography 7.

- 1939. The Kiliwa Indians of Lower California. Iberoamericana, Vol. 15.

SALES, Luis. 1960. Noticias de la Provincia de California 1794. J. Porrúa Turanzas, Madrid.

SHIPEK, Florence C. 1982. "Kumeyaay Socio-Political Structure". Journal of California and Great Basin Anthropology 4:296- 303.

- 1987. Pushed into the Rocks: Southern California Indian Land Tenure, 1769-1986. University of Nebraska Press, Lincoln.

- 1993a. "Las repercusiones de los europeos en la cultura Kumiai". Estudios Fronterizos 31/32:61-79.

- 1993b. "Kumeyaay Plant Husbandry: Fire, Water, and Erosion Management System". In: Thomas C. Blackburn and Kat Anderson (eds.), Before the Wilderness: Environmental Management by $\mathrm{Na}$ tive Californians. Ballena Press, Menlo Park, California.

TREGANZA, Adán E. 1947. "Possibilities of an Aboriginal Practice of Agriculture among the Southern Diegueño". American Antiquity 12:169-173. 